P. Samuel Fernández E.

Facultad de Teología U.C.

\title{
Regula fidei et rationis. Tradición, razón y Escritura en los primeros siglos
}

\section{A. EL PROBLEMA}

Felipe le preguntó al funcionario etíope: “Entiendes lo que vas leyendo?”, a lo que le contestó: “CCómo podría si nadie me guía?” (Hech 8, 30-31). Esta respuesta manifiesta un problema central de la hermenéutica, a saber, la insuficiencia del texto en sí mismo. No basta solo la lectura del texto; este necesita de guía para ser comprendido. Esta observación nos introduce en el tema de la relación entre el texto y los presupuestos que guían su interpretación, tema que sacudió con fuerza a la Iglesia primitiva.

El primer gran problema que enfrentó la Iglesia fue el de la observancia legal, es decir, si acaso los cristianos debían o no observar la ley de Moisés. Este problema está estrechamente relacionado con la hermenéutica bíblica: los literalistas tienden a la observancia literal, mientras los alegoristas a la observancia espiritual. Pero la primera Iglesia no contaba ni siquiera con un texto universalmente aceptado, y la pluralidad de interpretaciones del acontecimiento y del mensaje de Jesucristo amenazaban con despedazar esta comunidad original. En este contexto, el carácter eclesial de la lectura de las Escrituras llegó a ser un tema central en el debate teológico de la Iglesia naciente.

El período preniceno, en especial el siglo II, se revela particularmente adecuado para estudiar la relación entre las tradiciones interpretativas y la comunidad eclesial; entre la Escritura y la Iglesia; entre la tradición y la interpretación; entre la Escritura y las exigencias de la razón. Naturalmente, este período presenta condiciones irrepetibles, como el proceso de la formación del canon bíblico, pero sin duda deja lecciones permanentes, que siguen siendo instructivas hasta hoy.

El tema será abordado con una perspectiva histórica. Se tendrá en cuenta tanto el modo concreto con que los primeros grupos cristianos interpretaron las Escrituras, como las reflexiones de los primeros teólogos. Por lo tanto, primero se ofrecerán algunos ejemplos concretos de interpretación bíblica; luego se presentará la respectiva enseñanza de Tertuliano; para finalizar con las reflexiones conclusivas. 


\section{B. EJEMPLOS EXTREMOS DE INTERPRETACIÓN BÍBLICA}

Para introducirnos en el tema, es necesario tener en cuenta, a grandes rasgos, las singulares etapas del establecimiento del canon del Nuevo Testamento. En este proceso podemos distinguir tres momentos:

En un primer período, la Iglesia contaba con el texto del Antiguo Testamento y con el acontecimiento de Cristo transmitido oralmente. El único texto de carácter normativo era 'la Escritura', es decir, el AT. Se trata de un período muy instructivo para comprender la relación entre Tradición y Escritura, puesto que, durante algunas décadas, la Iglesia proclamó el kerygma sin un Nuevo Testamento escrito.

En un segundo momento, los textos que posteriormente pertenecerán al canon del NT ya estaban redactados, y circulaban independiente y heterogéneamente entre las comunidades; tenían autoridad por contener la tradición acerca de Jesús, pero aún no habían sido reunidos en un solo libro (1). Todavía no se les reconocía el carácter inspirado y, por lo tanto, aún no eran citados como 'Escritura'. El AT permanecía siendo el único texto con autoridad normativa. Así se explica la gran preocupación por la tradición oral de la que Jesús es la fuente (2).

El tercer período comienza a partir de la segunda mitad del siglo II, en que la Iglesia, tal vez forzada por la polémica antimarcionita (3), alcanzó un amplio acuerdo acerca de los libros que pertenecían al canon del Nuevo Testamento. Así, desde esta época, 'la Escritura' cristiana cuenta tanto con el Antiguo como con el Nuevo Testamento (4).

A continuación, se presenta algunos ejemplos que muestran la relevancia de las precomprensiones al momento de interpretar un texto bíblico. Se han tomado casos extremos y, por lo tanto, estos ejemplos no pretenden ser representativos de la exégesis patrística, sino casos límite para ilustrar la delicada relación entre la única Escritura y las diferentes tradiciones interpretativas. En la elección de los exegetas, se ha buscado incluir las diferentes, y a veces opuestas, tendencias cristianas: helenizados y judaizantes, griegos y latinos, asiáticos y alejandrinos, literalistas y alegoristas, ortodoxos y heterodoxos.

(1) Cf. B.M. Metzger, The Canon of the New Testament. Its Origen, Development, and Significance, Oxford 1997, pp. 39-73, en especial, pp. 72-73.

(2) Papías, a propósito de lo que recuerdan los que conocieron a algún discípulo del Señor, llegó a decir: "no me aprovecharía tanto lo que sacara de los libros como lo que proviene de una voz viva” (Eusebio, H.E., III, 39, 4). Algo semejante se podría decir del testimonio de Ireneo $($ Jesús $\rightarrow$ Juan $\rightarrow$ Policarpo $\rightarrow$ Ireneo).

(3) Cf. B.M. Metzger, The Canon of the New Testament, pp. 90-99

(4) Naturalmente, continuarán por varios siglos las oscilaciones entre el canon de una y otra iglesia, pero lo medular ya estará claro al finalizar el siglo II. 


\section{El Antiguo Testamento en el Nuevo Testamento}

Tanto los judíos como los cristianos del siglo I reconocían la autoridad normativa de 'la Escritura' (5), pero ¿qué significaba esa autoridad cuando el sentido del texto era, a veces, tan oscuro? Si el solo texto normativo fuera suficiente para mantener la unidad, cristianos y judíos habrían permanecido unidos, puesto que compartían las mismas 'Escrituras'; si de hecho no solo judíos y cristianos se separaron, sino que al interior de los creyentes en Cristo surgieron tantas facciones, fue porque el solo texto no bastaba para custodiar la unidad. Esta constatación muestra la importancia decisiva de la interpretación de las Escrituras.

Las citas de 'la Escritura' presentes en el NT son verdaderas interpretaciones del texto. El AT era leído e interpretado a la luz del acontecimiento de Cristo. De hecho, el AT era citado solo cuando podía ser interpretado a favor del punto tratado, y esa interpretación, a veces, solo podía ser alcanzada modificando la forma del texto (6).

Presentamos algunos ejemplos, tomados del libro de James Dunn, Unity and Diversity in the New Testament. En 2Co 3, 7-18, Pablo se refiere a Éx 34, 33-35, y explica el sentido del velo con que Moisés se cubría el rostro: mientras el Éxodo otorga un sentido positivo al velo, Pablo le atribuye uno negativo. El significado que Pablo da al velo de Moisés no depende tanto del texto del AT como de la propia teología paulina. Asimismo Mt 2, 23 afirma que Jesús "fue a vivir en una ciudad llamada Nazaret; para que se cumpliese el oráculo de los profetas: Será llamado Nazoreo”. No se ve claro a qué oráculo profético alude Mateo, pero lo que sí aparece claro es que la interpretación descansa no sobre la letra del AT sino sobre el acontecimiento de Cristo. Por otra parte, en el relato de los Hechos, cuando el funcionario de Candace pregunta respecto de un pasaje de Isaías, “De quién se dice esto: de sí mismo o de otro?” $(8,34)$, el contenido que se atribuya al texto dependerá más de las convicciones de Felipe que de la letra del texto de Isaías (7). También en el Evangelio de Juan "la Escritura es leída complexivamente como 'figura' que orienta a la verdad, que es Jesús” (8). El discurso cristiano en este período está guiado por la convicción de que Jesús de Nazaret es el Mesías que estaba anunciado por la Escritura (cf. Hech 17, 3). Ciertamente esta certeza es mucho más sólida que los argumentos bíblicos, tomados del AT, en que se la apoyaba. A la luz de la tradición acerca de Jesús, se tomaban algunos detalles de los textos del AT y se les otorgaban un significado que difícilmente se hallaba contenido en la letra de los textos mismos.

A partir de estos ejemplos, se ve claro que la interpretación de 'la Escritura' por parte de los autores del NT estaba determinada por el acontecimiento de Cristo y no por la letra del texto del AT. Para la primera comunidad, Cristo mismo es la

(5) La 'Escritura', en el ámbito cristiano del siglo I, equivale a nuestro actual Antiguo Testamento.

(6) Cf. J. Dunn, Unity and Diversity in the New Testament. An Inquiry into the Character of Earliest Christianity, London 1997, p. 94; E.E. Ellis, Paul's Use of the Old Testament, Eerdmans 1957, p. 144 (citado por Dunn).

(7) Este tipo de 'exégesis prosopográfica' será ampliamente practicada en la Iglesia antigua.

(8) G. Segalla, La scrittura nel Vangelo e nelle lettere di Giovanni, en E. Norelli (Ed.), La Bibbia nell' antichità cristiana, vol. I, Bologna 1993, p. 173. 
clave interpretativa del AT, maxime cuando Jesús en persona con su enseñanza sobrepasa y en ocasiones se opone a la letra de la Ley (9).

\section{Ignacio de Antioquía}

El modo de interpretar la Escritura (=AT) de Ignacio está fuertemente condicionado por la polémica contra los cristianos judaizantes. Ignacio es etnocristiano, es decir, uno de aquellos fieles de origen pagano que creyeron en el Cristo del kerygma, y solo después fueron introducidos en la lectura del AT. Las demostraciones proféticas no debieron hacer gran impresión entre estos cristianos que inicialmente no tenían ninguna simpatía por el Antiguo Testamento. Para ellos, el AT no tenía valor en sí mismo, sino solo en la medida que anunciaba a Jesucristo: primero creyeron en Cristo, y en función de Él se interesaron por el AT.

Mientras los cristianos judaizantes evaluaban a Cristo en base a las Escrituras, Ignacio y los suyos en base a Cristo evaluaban las Escrituras. Es decir, para los judaizantes el Cristo anunciado por la Iglesia valía en la medida en que estaba de acuerdo con las Escrituras; para Ignacio, por el contrario, la Escritura valía en la medida que estaba de acuerdo con el Cristo del kerygma. Mientras un cristiano judaizante diría: amemos a Jesús porque es el anunciado por los profetas, Ignacio afirma: "Amemos a los profetas porque ellos anunciaron el evangelio" (10). Esta situación queda bien ilustrada en un famoso y controvertido pasaje de su Carta a los Filadelfios:

He oído a algunos que decían: "Si no lo encuentro en los archivos ('̇v toîs $\alpha \rho \chi \varepsilon i ́ o \iota \varsigma)$, no creo en el evangelio". Les dije: "Está escrito" ( $\gamma \varepsilon \dot{\gamma} \rho \alpha \pi \tau \alpha \iota)$. Me respondieron: "Muéstralo". Para mí los archivos son Jesucristo ('Euoí $\delta \varepsilon \dot{\varepsilon}$

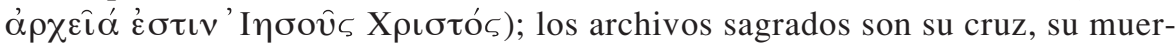
te, su resurrección y la fe que viene de Él, en los cuales quiero ser justificado por vuestra oración (11).

El texto es elocuente si consideramos que la opinión común de los estudiosos es identificar "los archivos" con la Escritura, es decir, con el AT (12). Para Ignacio lo decisivo no es el Antiguo Testamento, sino Jesucristo. Sus adversarios dudan de

(9) Cf. el apartado 16.2 Jesus' attitud to tradition, en J. Dunn, Unity and Diversity in the New Testament, pp. 63-64, y p. 98.

(10) Ignacio, A los Filadelfios, V, 2: “Amemos también a los profetas porque ellos anunciaron el evangelio, esperaron en Él y lo aguardaron. Por haber creído en Él, se salvaron, pues estaban en la unidad de Jesucristo; eran santos, dignos de amor y de admiración, atestiguados por Jesucristo" (FP 1, p. 163).

(11) Ignacio, A los Filadelfios, VIII, 2 (FP 1, p. 165).

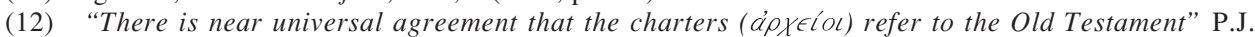
Donahue, Jewish Christianity in Ignatius' Letters, VC 32 (1978) p. 86. Cf. W.R. Schoedel, Ignatius and the Archives, HThR 71 (1978) pp. 97-106; B.M. Metzger, The Canon of the New Testament, p. 48. En realidad, habría que ser más cuidadoso, y no unificar excesivamente las Escrituras como un solo bloque. Puede ser que Ignacio designe con el nombre de "archivos" no a nuestro Antiguo Testamento completo, sino a la Ley en particular. Así se comprende mejor su simpatía por los profetas en un contexto de desinterés y cierta aversión por la Ley de Moisés (en las 7 cartas de Ignacio no hay ninguna cita explícita tomada del Pentateuco). 
la interpretación cristológica del AT, y creen en el Evangelio solo en la medida que este esté de acuerdo con el AT; Ignacio cree en Jesucristo y su Evangelio, y si en algo se interesa por el AT es porque cree que él habla de Cristo. En un tiempo en que 'las Escrituras' de los cristianos son el AT, Ignacio no demuestra gran devoción por estas Escrituras, y basa su fe no en el texto normativo sino en la predicación eclesial.

\section{Marción}

El desinterés de Ignacio por el AT, llevado al extremo, conduce a la postura de Marción. Este no solo se desinteresa, sino que desecha el AT. Para él, el cristianismo se basa en Jesucristo, y nada tiene que ver con la Escritura de los judíos. Marción establece como criterio hermenéutico la oposición entre Ley y Evangelio: "Todo lo que elaboró Marción... mira a esto: establecer la diversidad entre el Antiguo y el Nuevo Testamento; por lo tanto, [presentar] a su Cristo separado del Creador; como Dios de otro, como extraño a la Ley y a los profetas" (13). Una vez establecido este principio, examina e interviene los textos del NT. Tertuliano denuncia este procedimiento: extirpó las afirmaciones que eran contrarias a su doctrina (14). A la luz de su propio principio hermenéutico, no solo interpreta los textos sagrados, sino que los modifica.

Veamos algunos ejemplos. Respecto de la interpretación marcionita de un versículo de Efesios, Tertuliano comenta:

No me sorprendo de las manos del hereje (que deben ser cortadas), me admiro cuando roba unas sílabas, en circunstancias que muchas veces ha arrancado páginas completas. Dice el Apóstol que a él, último entre todos, le ha sido concedida la gracia de iluminar a todos cuál es la economía del misterio oculto desde los siglos en Dios ('́v $\tau \hat{\omega} \hat{\varphi} \theta \varepsilon \hat{\omega})$, que creó todo (15). El hereje extirpó la

(13) Tertuliano, Adversus Marcionem, IV, 6, 1. Cf. S. Fernández, La salvación sin mediaciones según Marción y la respuesta de Tertuliano, TyV XLII (2001) pp. 50-73. En su interés por tener 'Escrituras propias', Marción será el primero -de acuerdo a nuestra documentación- en reunir el Evangelio y las cartas de Pablo en un solo códice, consituyendo así el primer 'Nuevo Testamento', que llama Instrumentum. En ámbito católico, Ireneo es el primero en utilizar 'Escritura' para referirse al Nuevo Testamento, ver Adv. haer., III, 19, 2. Cf. R. Polanco, El concepto de profecía en la teología de san Ireneo, BAC, Madrid 1998, pp. 212-215.

(14) Tertuliano, Adversus Marcionem, IV, 6, 1: “Todo lo que elaboró Marción... mira a esto: establecer la diversidad entre el Antiguo y el Nuevo Testamento; por lo tanto, [presentar] a su Cristo separado del Creador; como Dios de otro, como extraño a la Ley y a los profetas”. Cf. Ireneo, Adv. haereses, I, 27, 1: "Además, [Marción] mutila el contenido del Evangelio según Lucas, eliminando todas las narraciones concernientes a la generación del Señor, así como también muchos puntos doctrinales de las palabras del Señor. Los eliminados son, precisamente, los pasajes en los que Jesús manifiesta que el Creador del mundo es su Padre. [...] De igual manera recorta las epístolas de Pablo, eliminando todo lo que el apóstol declara abiertamente acerca del Dios Creador del mundo, identificado con el Padre de Nuestro Señor Jesucristo, y suprimiendo también todo lo que Pablo enseña apoyándose en los profetas que predijeron el advenimiento del Señor".

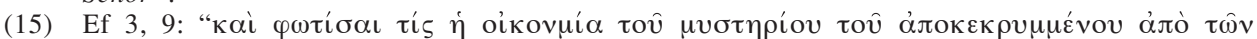

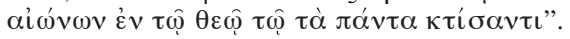


preposición “en” y así hace que se lea: oculto desde el siglo, al Dios $(\tau \hat{\varphi} \hat{\theta} \theta \varepsilon \hat{\varphi})$ que creó todo (16).

La pequeña intervención textual de Marción cambia por completo el sentido del texto bíblico, haciéndolo funcional a su doctrina que afirma que el Dios del AT, el Creador, permaneció desde los siglos en total ignorancia de la economía cristiana (17).

Efectivamente, Marción había arrancado páginas completas del Evangelio. Convencido de un estricto docetismo cristológico, hacía comenzar su evangelio con la siguiente combinación de versículos: "En el año quince del imperio de Tiberio César, siendo Poncio Pilato procurador de Judea, Jesús bajó [del cielo] a Cafarnaún, ciudad de Galilea, y los sábados les enseñaba” (18). De este modo, el Cristo marcionita nada tiene que ver con la humanidad ni con la Ley.

Asimismo, reafirma el docetismo modificando esta vez solo la entonación de la lectura de un texto: Tertuliano transmite el argumento que utilizan los docetas: "Cristo mismo afirma que Él no ha nacido cuando declara: ‘Quién es mi madre, y quiénes son mis hermanos?”' (19), como si Jesús dijera que no tiene madre ni hermanos.

De este modo, ya sea modificando o interpretando los textos, Marción es capaz de confirmar sus doctrinas con el texto sagrado. El criterio hermenéutico de la contraposición entre Ley y Evangelio determina la lectura marcionita de la Escritura.

\section{La literatura Pseudoclementina}

Al extremo opuesto de Marción se ubica la literatura pseudoclementina. Ella contiene elementos del siglo II, proviene de un ambiente judeo-cristiano, acepta el AT leído a la letra, es partidaria de la observancia literal de la Ley y es antipaulina (20).

Pero hasta los judeocristianos más entusiastas del AT reconocen textos que no pueden ser aceptados literalmente. La homilía II reporta una larga lista de antítesis, que muestran algunas aparentes contradicciones al interior del AT: el largo texto se refiere a la ignorancia de Dios referida por el Génesis, su arrepentimiento después del diluvio, el endurecimiento del corazón del Faraón en el Éxodo, su necesidad de grasa, sacrificios y sangre; pero el autor de estas homilías insiste en que Dios no es

(16) Tertuliano, Adversus Marcionem, V, 18, 1.

(17) Como se puede comprobar en una buena edición crítica del NT, la intervención de Marción pasó a varios códices importantes del Nuevo Testamento.

(18) Se trata de la combinación de Lc 3, 1 y 4, 31. Marción elimina toda la infancia de Jesús, que lo relaciona con el mundo y con la Ley. Cf. A. v. Harnack, Marcion. Das Evangelium vom fremden Gott (TU, 45), Leipzig 1924, p. 183*-184*; Tertuliano, Adversus Marcionem, IV, 7: “de caelo statim ad synagogam”.

(19) Tertuliano, Adversus Marcionem, V, 11, 9.

(20) La literatura pseudoclementina contiene un Grundschrift, es decir, un escrito base, que se remonta al siglo II ó III, que ha sido posteriormente reelaborado e interpolado. Cf. J. Irmscher, en E. Hennecke-W. Schneemelcher, The New Testament Apocrypha, SCM Press 1965, vol. II, p. 533; H. Köstler, Introducción al Nuevo Testamento, Salamanca 1988, p. 726; J. K. Elliott, The Apocryphal New Testment, Oxford 1993, p. 431. 
ignorante, ni se arrepiente, ni endurece los corazones, ni necesita sacrificios (21). ¿Cómo se resuelven, entonces, estas contradicciones?

Las homilías afirman que las Escrituras contienen elementos falsos, que han sido introducidos por el enemigo, e invitan a una programática exclusión de estos elementos:

Las Escrituras han recibido muchas cosas falsas en contra de Dios ( $\pi 0 \lambda \lambda \dot{\alpha} \gamma \dot{\alpha} \rho$

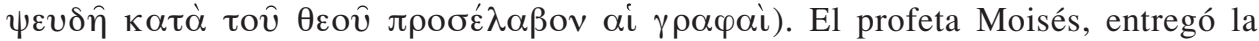
Ley con explicaciones, por orden de Dios, a ciertos hombres elegidos, unos 70, para que ellos pudieran instruir al pueblo elegido, y poco después le fueron agregadas a la Ley ciertas falsedades contrarias a la Ley de Dios (22).

El criterio para identificar lo falso aparece simple: "Todo lo que se dice o está escrito [en la Escritura] en contra de Dios es falso” (23). Ahora bien, queda claro que el criterio que discrimina entre la auténtica y la falsa Escritura no puede provenir de la Escritura misma, y se establece un criterio de juicio por sobre la Escritura. Curiosamente, el mayor enemigo de Marción termina por aplicar la misma técnica que su adversario: la exclusión de los textos que no se armonizan con su propia doctrina (24). De este modo, los que aprecian con mayor veneración la letra del AT y pretenden 'no interpretarla' sino simplemente observarla, paradójicamente, terminan por modificar burdamente el texto sagrado, porque en algunos casos el texto les resulta inaceptable. La letra de la Escritura es inaceptable cuando contradice la propia tradición doctrinal o cuando va contra lo razonable. Nuevamente, los presupuestos con que se lee el texto bíblico son los que mandan la interpretación.

\section{Ptolomeo y otros gnósticos}

La Carta a Flora de Ptolomeo, único documento valentiniano que nos ha llegado completo y en su lengua original, ofrece datos valiosísimos para conocer la interpretación gnóstica de la Escritura.

En su afán por mostrar la contradicción entre AT y NT, para poder así contraponer el Dios de la Ley y el Padre de Cristo, Ptolomeo se vale de una exégesis muy simple, guiada por una lógica implacable: La Ley no puede provenir de un Dios perfecto, porque es imperfecta, necesita ser completada $(\pi \lambda \eta \rho \omega \theta \hat{\eta} v \alpha \iota)$ por otra (3, 4). Ofrecemos un ejemplo:

En la discusión sobre el divorcio -cuya licitud establecía la ley- dijo el Salvador a sus adversarios: "Moisés permitió repudiar a la propia mujer a causa de vuestra dureza de corazón. Pero al principio no era así. Pues Dios -prosigueha hecho esta unión, y está escrito que lo que Dios unió no lo separe el hombre" (Mt 19, 8.6). Aquí pone de manifiesto que hay una ley de Dios que prohíbe separar a una mujer de su marido y otra de Moisés que, a causa de la

(21) Cf. Ps.-Clemente, Hom., II, 43-44 (GCS I, 53, 4-8). Estas 'antítesis' debieron ser respuesta a las objeciones gnósticas y marcionitas.

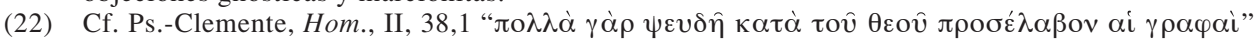
(GCS I, 51). Cf. II, 43.44.52; III, 43; XVIII, 20.

(23) Ps.-Clementina, Hom., II, 40.

(24) De Lubac llama este procedimiento 'una maniobra desesperada', cf. H. De Lubac, Histoire et Esprit. L'intelligence de l'Écriture d'après Origène, Théologie 16, Paris 1950, p. 54. 
dureza de corazón, permite la ruptura de esta unión. Según esto, Moisés legisla de modo contrario a Dios, pues separarse es lo contrario de no separarse. [...] Es indiscutible que el testimonio aducido demuestra que la ley de Moisés es distinta de la ley divina (4, 4-6.10).

Ptolomeo demuestra exegéticamente el diteísmo gnóstico, es decir, que existe un dios inferior (el del AT) y otro Dios Supremo (el Padre de Cristo). Esta afirmación es inaceptable para los cristianos católicos del siglo II. Pero lo que se debe reprochar a Ptolomeo no es su falta de habilidad exegética, sino su punto de partida, es decir, su diteísmo gnóstico.

Otros grupos gnósticos, convencidos de la oposición entre AT y NT, interpretaban negativamente a los buenos y ensalzaban a los malos del AT. Incluso hubo una secta que veneraba la serpiente del paraíso (la primera en oponerse al dios justiciero); y otra que se puso de parte de Caín, llamada 'los cainitas', puesto que el cruel dios del AT habría preferido a Abel, que le había sacrificado un cordero, y rechazado a Caín, que le había ofrecido frutos de la tierra, puesto que era un dios al que le gustaba la sangre (25). El Ps.-Hipólito transmite una radical interpretación de Juan 10, 8: "Todos los profetas y la Ley, necios e ignorantes de todo, hablaron del Demiurgo como de un dios necio. Por eso dice el Señor: 'Todos los que me han precedido son ladrones y salteadores'” (26). La Ley y los profetas serían los "ladrones y salteadores'.

Nuevamente, el error no estaría en el procedimiento exegético (semejante al que se aplica a la parábola de 'los viñadores homicidas'), sino en las convicciones anteriores a la lectura del texto.

\section{Tertuliano}

Un buen ejemplo para ilustrar la actitud de Tertuliano son sus comentarios a la interpretación marcionita de un versículo de II Corintios (27):

Sabemos -afirma Tertuliano- que algunos significados pueden sufrir una ambigüedad a partir del sonido de la pronunciación o del modo de la puntuación, cuando se da una duplicidad de ellas. Marción las captó leyendo así: "en los cuales, el Dios de este siglo", para mostrar al Creador como 'Dios de este siglo', y sugerir otro 'Dios de otro siglo'. Pero nosotros, puntuando así, pronunciamos: “En los cuales el Dios, encegueció las mentes de los incrédulos de este siglo”. 'En los cuales', es decir, en los judíos incrédulos (28).

(25) Cf. Ps.-Hipólito, Refutatio, V, 19, 6: “Caín es aquel cuya ofrenda no fue aceptada por el dios de este mundo, quien, en cambio, aceptó el sangriento sacrificio de Abel; pues el dueño de este mundo se deleita en la sangre”, cf. Gn 2, 10-14; 4.15.35.

(26) Ps.-Hipólito, Refutatio, VI, 35, 1.

(27) Se trata de 2Cor 4, 3-4: "Y si todavía nuestro Evangelio está velado, lo está para los que se pierden, para los incrédulos, cuyo entendimiento cegó el dios de este mundo para impedir que vean brillar el resplandor del Evangelio de la gloria de Cristo, que es imagen de Dios". La dificultad radica en la identidad del 'Dios de este mundo', que Marción identificó con el Dios del AT, el Creador.

(28) Tertuliano, Adversus Marcionem, IV, 19, 6. 
En este caso, Marción toma la lectura más adherente al texto, mientras Tertuliano recurre a una lectura evidentemente forzada para poder salir del paso. Y lo más sorprendente es que, en la misma obra, Tertuliano adopta un par de lecturas distintas del mismo versículo. Para el autor latino 'el Dios de este siglo' ipuede ser el Diablo o el Dios Creador!, dependiendo de cómo se lea al Apóstol (29). Así, Tertuliano ante $2 \mathrm{Co} 4,4$, que en su lectura literal es funcional a Marción, ensaya tres interpretaciones contrapuestas, de acuerdo a su conveniencia argumentativa. Es evidente que lo que manda su interpretación no es la letra del texto, sino sus convicciones teológicas anteriores.

Por otra parte, para refutar el diteísmo marcionita, bien fundamentado en base a las antítesis bíblicas (30), Tertuliano recurre también a la razón: "Dios, si no es uno, no es; porque creemos que es más digno (dignius) que no exista aquello que no es tal como debería ser" (31). Además, "negaremos que sea Dios aquel en el cual no consten todas las [características] dignas de Dios” (32). Así, aun si la Biblia parece decirlo, las cosas no pueden ser sino 'como deben ser'. Naturalmente, surge la pregunta ¿quién establece cómo deben ser las cosas?, o ¿qué es digno de Dios? Pero lo que interesa destacar es que la interpretación del texto bíblico está guiada por convicciones racionales anteriores a la lectura del texto.

\section{Orígenes de Alejandría}

El más grande de los exegetas de la antigüedad cristiana, conocido por su autonomía de pensamiento y libertad hermenéutica, también impone a la Escritura los límites de la regula fidei y de la razón. Presentamos como ejemplo su explicación de un versículo que, en su lectura literal, contradice la regla de fe. Se trata de Ex 20, 5: "Yo soy el Señor, tu Dios, Dios celoso que castiga los pecados de los padres en los hijos, hasta la tercera y cuarta generación":

¿A quién no turba esta palabra? Si pecó el padre, reciben el pecado el hijo, la tercera y la cuarta generación. Algunos acusan al Dios dador de la Ley [...] El eclesiástico no escucha corporalmente lo dicho, como el judío, ni se inventa otro [Dios], como el hereje, sino que se ubica en medio de ambos y afirma que

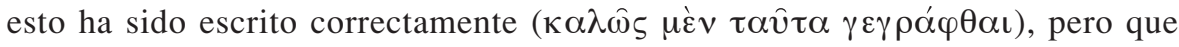
no conoce el sentido de lo escrito. Eleven sus pensamientos y rueguen para que les sea revelado cómo es bueno aquel que castiga los pecados de los padres en los hijos. ¿Quiénes son los padres? Ten la Escritura como testigo. Escrutemos las palabras sagradas. Dice el Salvador y Señor, Jesús Cristo, a los pecadores:

(29) Cf. Tertuliano, Adversus Marcionem V, 17, 9: "Este será el diablo, al que en otro lugar, si acaso quieren que así se lea al Apóstol, reconocemos dios de este siglo. A tal punto llenó todo el siglo con la mentira de su divinidad. El que si efectivamente no existiese [el diablo], entonces estas [palabras] podrían corresponder al Creador".

(30) Marción, al oponer antitéticamente textos del AT y del NT, mostraba la distinción entre el Dios de uno y otro testamento.

(31) Tertuliano, Adversus Marcionem, I, 1, 1 "Deus si non unus est, non est, quia dignius credimus non esse quodcumque non ita fuerit, ut esse debebit”.

(32) Tertuliano, Adversus Marcionem, I, 25, 2 "Negabimus Deum in quo non omnia, quae Deo digna sint, constent”. De acuerdo a I, 13, 2 también Marción utilizaba el 'Deo dignus' como criterio de discernimiento. 
“Ustedes son del padre, el diablo. Y quieren realizar los deseos del padre de ustedes, Aquel es homicida desde el principio, y no subsistía en la verdad" (Jn 8, 44). En consecuencia, si uno peca, es del padre, el diablo, y por esto el pecado del diablo se castiga en el hijo. En realidad, el diablo es el primer pecador, que introduce secretamente el pecado en mí; yo, en cambio, soy el pecador secundario que no rechaza la voluntad del primero, sino que ha aceptado su acción [...]. De este modo, si soy santo, tengo a Dios por padre; pero si soy pecador, tengo al diablo por padre (33).

No pretendemos juzgar el contenido de la exégesis, sino comprender el procedimiento hermenéutico. Orígenes afirma: 'esto ha sido escrito correctamente', guiado por la convicción de la inspiración bíblica, y no por alguna evidencia que proceda del texto, puesto que la lectura literal de este versículo es insostenible, pues contradice la bondad de Dios, y afirma de Dios cosas que no se podrían pensar ni siquiera del más injusto de los hombres (34). A continuación se pregunta: ¿Cómo es bueno aquel que castiga los pecados de los padres en los hijos?, lo que equivale a preguntarse: ¿Cómo interpretar este versículo en modo que no contradiga la regla de fe? Puesto que el texto parece oponerse al monoteísmo, a la bondad de Dios y al libre albedrío (35). El monoteísmo, la bondad de Dios, el libre albedrío y la inspiración bíblica son artículos de la regula fidei que Orígenes ha recibido como certezas incuestionables que guían la explicación de este difícil versículo (36).

Por otra parte, afirma que los suplicios que Dios impone se deben comprender de modo digno de Dios (quasi digna Deo) (37). Al igual que Tertuliano, el Alejandrino está convencido que lo que dice la Escritura debe ser comprendido en modo digno de Dios: "Pero nosotros, cuando leemos algo referido a la ira de Dios, ya sea en el Antiguo como en el Nuevo Testamento, no interpretamos literalmente lo dicho, sino que investigamos su comprensión espiritual, para que comprendamos de tal manera que sea digno de Dios" (38). Así, la bondad de Dios se vuelve un principio para interpretar la Escritura: todo lo que viene de Dios es bueno (39). A pesar de que la Biblia muchas veces revela la ira de Dios y oculta su bondad, Orígenes sabe que Dios es bueno y que la ira le es extraña (40). Aquí, no solo está en juego la regla de

(33) Orígenes, Selecta in Exodum, ad Ex XX, 5-6. PG XII 289c-292b.

(34) Cf. Orígenes, De principiis, IV, 2, 1.

(35) El monoteísmo está en juego, pues si el Dios del AT no es bueno (y este ni siquiera es justo), debería haber otro Dios que sí fuese bueno, es decir, el Padre de Cristo.

(36) La regla de fe recibida por Orígenes está expuesta en De principiis, I, praef., 4-8; In Joh. Com., XXXII, 187-189; In Tit. fr. PG XIV 1303-1305; In Jer. hom., V, 3; Ser. Matth., 33. Cf. R.C. Baud, Les “Règles” de la théologie d'Origène, RSR 55 (1967) pp. 161-208.

(37) Cf. Orígenes, In Ezequielem hom., V, 1: "et supplicia, quae ab eo irrogantur, sic intelligere, quasi digna Deo et convenientia dispensationi eius, nos vult, non tantummodo cruciari”: (GCS, VIII 372, 25-27).

(38) Orígenes, Princ., II, 4, 4.

(39) Cf. Orígenes, In Ezequielem hom., I, 2: “Omnia quae Dei sunt, bona sunt” : (GCS, VIII 322, 3).

(40) Cf. Orígenes, In Rom. Com., VII, XVIII: "Nam iram quidem Dei quae est a natura ejus extranea, notam fieri hominibus dicit, sicut praesens hic Apostoli indicat locus: bonitatem vero ejus, et dulcedinem, quod naturae ejus est proprium, abscondi memorat, et occultari, sicut David dicit: "Quam magna multitudo dulcedinis tuae, Domine, quam abscondisti timentibus te!" Quid ergo causae dicemus quod Deus iram manifestat hominibus, et dulcedinem celat?”: (PG, XIV 1150C-

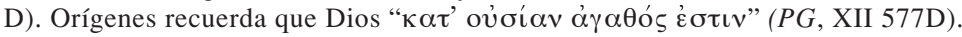


fe, sino las exigencias de la razón. De modo semejante, cualquier cosa absurda o imposible, narrada por la Escritura, debe ser interpretada alegóricamente (41).

Asimismo, estas exigencias de la razón llevan a Orígenes a rechazar las expresiones antropomórficas acerca de Dios: "todo lo que operan las potencias divinas, a fin de que los hombres puedan entenderlo, se presenta con el nombre de miembros humanos, o se enuncia por medio de sentimientos comunes y conocidos. En este sentido se dice que Dios se aira, oye o habla" (42). Este tipo de afirmaciones, también referidas a los antropomorfismos, ya se encontraban en Clemente de Alejandría: "no es posible hablar de la divinidad tal como es en realidad, sino tal como a nosotros nos es posible entender, envueltos en la carne” (43). Más que el denso contenido de los pasajes citados, nos interesa destacar que Orígenes interpreta los antropomorfismos bíblicos a la luz de un principio que es anterior a la letra del texto.

De este modo, ni siquiera el más libre de los exegetas está dispuesto a contrariar la regla de fe o la razón con su interpretación bíblica. Por el contrario, el mismo Orígenes declara en De principiis que, para comprender la Escritura, es necesario

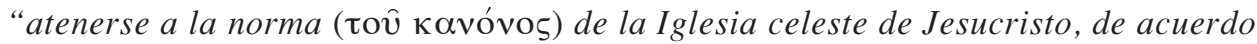
a la sucesión de los apóstoles" (44). Nuevamente, las convicciones anteriores, tanto de la tradición eclesial como de la razón, guían la interpretación del texto bíblico. El desarrollo de la exégesis alegórica estará en relación con la exigencia de comprender los textos bíblicos en modo de no contradecir ni la regla de fe ni la sana razón.

\section{La corrupción "ortodoxa" de las Escrituras}

Los autores ortodoxos acusaron a los herejes de corromper las Escrituras (45). Pero contamos con evidencia de que los copistas ortodoxos, por motivos doctrinales, en algunas ocasiones, modificaron el texto sagrado (46). En el fragor de las controversias cristológicas, los versículos 'favorables' a los herejes eran susceptibles de ser modificados por los copistas. El amanuense por lo general no es un teólogo, sino un representante de la fe de la Iglesia. Presentamos algunos ejemplos:

1. Antiadopcionista. En varios versículos de las narraciones lucanas de la infan-

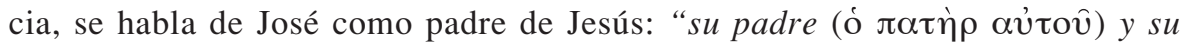
madre estaban admirados de lo que se decía de él” (2, 33); "el niño Jesús se

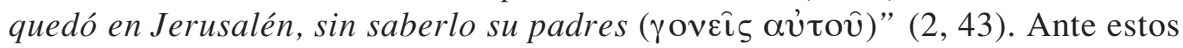

(41) Cf. J. Pépin, A propos de l'histoire de l'exégèse allégorique: l'absurdité, signe de l'allégorie. Studia Patristica I (TU, 63), Berlin 1957, pp. 397-400.

(42) Orígenes, In Gen. hom., III, 2 (GCS VI, pp. 39-40). Es conocida la polémica de Orígenes contra los antropomorfitas: "Scio quoniam conabuntur quidam etiam secundum scripturas nostras dicere Deum corpus esse": (Princ., I, I, 1; cf. In Canticum Com., III, 13, 46). Cf. M. Simonetti, I Principi di Origene, Torino 1968, p. 127 n. 2; H. Crouzel, Théologie de l'Image de Dieu chez Origène, Paris 1956, p. 63 y pp. 153-160.

(43) Clemente, Strom., II, 72, 4 (FP 10, p. 193).

(44) Orígenes, De principiis, IV, 2, 2.

(45) Cf. Dionisio de Alejandría en Eusebio, HE IV, 23.

(46) En este apartado sigo a B.D. Ehrman, The Ortodox Corruption of Scriptures. The Effect of Early Christological Controversies on the Text of the New Testament, Oxford University Press 1993. 
textos funcionales a una cristología adopcionista, algunos escribas sistemáticamente reemplazaron "su padre" por "José", y "sus padres"

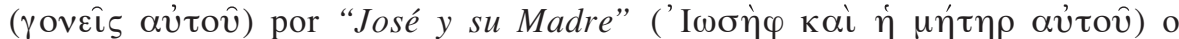
simplemente por "José y María” (47).

2. Antignóstico. En Juan 10, 8 Jesús afirma: "Todos los que han venido antes de mí son ladrones y salteadores". La expresión es favorable a los enemigos del AT. Todos los que han venido antes de mí, es decir, los patriarcas y los profetas, son ladrones y salteadores, comprendieron algunos gnósticos. Ante esta dificultad, algunos copistas optaron simplemente por omitir $\pi \alpha ́ v \tau \varepsilon \varsigma$, atenuando así la afirmación de Jesús (48).

3. Antipatripasiano. Hechos 20, 28 habla de "la Iglesia de Dios, que él se adquirió con su propia sangre”. El sentido inmediato del texto favorece la teología patripasiana, que afirma que el Dios Único padeció en la cruz. Motivados por

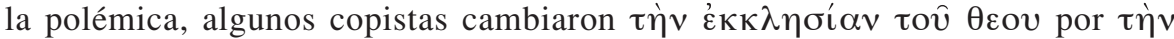

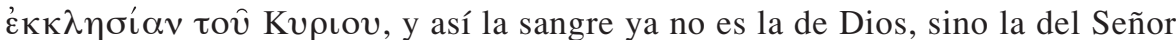
Jesús. Asimismo, “el que me ha visto a mí, ha visto al Padre” (Jn 14, 9), acepta una interpretación monarquiana que identifica personalmente al Hijo y al Padre; algunos copistas integraron un кai en modo que el texto se lea: "el

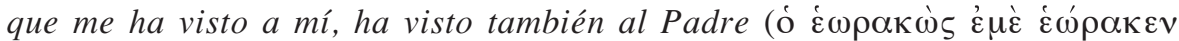

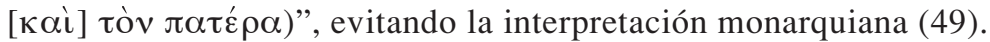

Estas variantes textuales no son fruto de la distracción, sino intervenciones conscientes, por motivos doctrinales. Es tanta la seguridad doctrinal del amanuense, que se atreve a modificar el texto sagrado, cuando este parece afirmar algo contrario a la regla de fe. La precomprensión del lector no solo determina la interpretación del texto sino, en algunos casos, incluso su forma.

\section{REFLEXIÓN DE TERTULIANO}

Esta serie de ejemplos de casos extremos que hemos visto, muestran el protagonismo de las diversas precomprensiones en la interpretación de la Escritura. Esto no pasó inadvertido a los teólogos cristianos. Entre quienes reflexionaron el tema, se destacan Ireneo y Tertuliano. En nuestra exposición, tomaremos el testimonio de Tertuliano, por ser más sistemático, y haremos algunas alusiones a Ireneo.

Tertuliano afirma que "los herejes siempre arrastran donde quieren, con sus conjeturas, las sentencias simples y a la letra, o por el contrario, en la lectura literal, [les] quitan valor bajo ciertas condiciones y razones" (50). La misma queja

(47) Cf. B.D. Ehrman, The Ortodox Corruption of Scriptures, pp. 54-57. Los manuscritos que testifican estas modificaciones son abundantes, y están a la vista en una buena edición crítica del Nuevo Testamento.

(48) Cf. Ps.-Hipólito Refutatio, VI, 35, 1. Vide supra; B.D. Ehrman, The Ortodox Corruption of Scriptures, p. 240.

(49) Cf. B.D. Ehrman, The Ortodox Corruption of Scriptures, p. 264-265.

(50) Tertuliano, Adversus Marcionem, V, 11, 9. Cf. Ireneo, Adversus haereses, IV, 35, 4: “iTantas son las diversas interpretaciones que dan acerca de un mismo texto de la Escritura, de donde brotan sus diversas doctrinas!". 
se lee en Ireneo que afirma que los herejes 'adaptan' la Escritura a sus propios propósitos (51). Pero, de acuerdo a los ejemplos presentados, ¿son solo los herejes los que 'siempre arrastran donde quieren' el contenido de los textos bíblicos? ¿Quién tiene autoridad para discernir la interpretación correcta? ¿Qué criterios conducen a una correcta interpretación bíblica?

Se plantea el problema de la relación entre la fe eclesial y el texto sagrado, es decir, entre la Tradición y la Escritura. Ireneo declara que los apóstoles "primero proclamaron [el Evangelio], después (postea), por voluntad de Dios, nos lo transmitieron por escrito" (52), y dice que aun si los apóstoles no hubiesen escrito, hubiese bastado la Tradición eclesial (53). Tertuliano, por su parte, afirma también que "el testimonio es anterior a los documentos” (54), y recuerda que los apóstoles primero predicaron de viva voz y después (postea) por medio de escritos (55).

Basándose en este hecho evidente, Tertuliano, radical y agudo como siempre, distingue 'doctrina' de 'Escritura', y afirma que lo más original es la 'doctrina', es decir, la fe enseñada por Jesús que ha sido transmitida por medio de la Tradición apostólica, y, por tanto, las Escrituras forman parte de la Tradición. De este modo, "la Escritura no es lo primero y lo original (por tanto, no es la última instancia en un posible pleito); lo primero y original es la doctrina, a la que la Escritura estará siempre subordinada como su instrumento" (56). Esto significaría que la regla de fe tiene una cierta prioridad sobre la Escritura. De ahí que Tertuliano intente probar la validez de las Escrituras en base a la regla de fe (57). En un texto que describe el comportamiento de los herejes, propone las dificultades centrales:

La herejía no admite ciertas Escrituras; y si admite algunas, no las admite íntegras, sino que las altera con añadiduras y supresiones de acuerdo con la ordenación de su sistema; y, si hasta cierto punto las mantiene íntegras, las cambia, sin embargo, componiendo interpretaciones contrarias (De praes., 17, 1).

Este pasaje plantea tres diferentes problemas en torno a la Escritura: Su canonicidad, su integridad y su interpretación. Estos mismos problemas aparecen juntos en un texto de Ireneo (58). Si bien el que más nos interesa es el de la interpretación, los dos anteriores son fundamento necesario para tratar este último.

(51) Ireneo, Adversus haereses, I, 8, 1: “Y no les preocupa acomodar a sus doctrinas, de una manera confiable, sea las parábolas del Señor, sea los dichos de los profetas, sea la predicación de los Apóstoles. [...] Transponen y transforman todo y, mezclando una cosa con otra, seducen a muchos mediante la fantasiosa composición que fabrican a partir de las palabras del Señor".

(52) Ireneo, Adversus haereses, III, 1, 1: "Non enim per alios dispositionem salutis nostrae cognouimus quam per eos per quos Euangelium peruenit ad nos: quod quidem tunc praeconauerunt, postea uero per Dei uoluntatem in Scripturis nobis tradiderunt, fundamentum et columnam fidei nostrae futurum".

(53) Cf. Ireneo, Adversus haereses, III, 4, 1-2.

(54) J.N.D. Kelly, Early Christian Doctrines, London 1977, p. 33.

(55) Cf. Tertuliano, De praes., 21, 3; R.P.C. Hanson, Tradition in the Early Church, London 1962, p. 103.

(56) S. Vicastillo, en Tertuliano, “Prescripciones" contra todas las herejías (FP 14), Madrid 2001, pp. 106-107.

(57) Cf. Tertuliano, De praes., 37, 1; R.P.C. Hanson, Tradition in the Early Church, p. 108.

(58) Cf. Ireneo, Adversus haereses, IV, 33, 8. 
1. En el siglo II, la canonicidad de un escrito era un tema candente. Sin entrar en detalles, basta recordar que, entre los cristianos, los católicos admitían los cuatro evangelios, los ebionitas aceptaban solo el de Mateo o el de los Hebreos, los marcionitas solo el de Lucas, mientras los gnósticos daban su preferencia a Juan, y circulaban además otros evangelios; en relación con Pablo, los ebionitas lo llamaban 'el Apóstata de la Ley' o 'el Enemigo', y rechazaban sus cartas (59), mientras católicos y gnósticos las aceptaban, y llamaban a Pablo simplemente 'el Apóstol'; los marcionitas, por su parte, aceptaban sus cartas con tanto entusiasmo que las consideraban el principio hermenéutico de toda la revelación cristiana. No sin razón Tertuliano llega a llamar a Pablo 'el Apósol de los herejes' (60).

En síntesis, en el siglo II no hay un solo texto del NT que goce de autoridad en todos los grupos cristianos. Al estudiar la accidentada historia del canon del Nuevo Testamento, queda de manifiesto el carácter operativo de esta 'cierta prioridad' de la Iglesia sobre el texto sagrado. Es la Comunidad eclesial la que 'juzga' si un determinado texto está o no de acuerdo con la regla de fe, lo que es el primer prerrequisito para pertenecer al NT (61).

El siglo II es particularmente importante en este proceso, puesto que se debe confiar 'primero' en la comunidad, para confiar 'después' en el texto sagrado (62). Siglos más tarde, Agustín expresará este concepto con su acostumbrada maestría: "Ego vero Euangelio non crederem, nisi me Catholicae Ecclesiae conmoueret auctoritas" (63); es decir, 'Creo en el Evangelio, porque creo en la Iglesia'.

2. En esta época era frecuente modificar los textos bíblicos en función de su uso polémico. Las acusaciones mutuas abundan. El propio Tertuliano delata la práctica de los herejes: "Corrompen la Palabra de Dios, que se ha hecho carne, ya sea con la pluma ya sea con la interpretación” (64), es decir, modificando o interpretando los textos. La práctica no estaba circunscrita a un solo grupo; hemos visto a cristianos católicos, a marcionitas y a judeocristianos modificando los textos sagrados. ¿Cómo resolver este problema? No había una versión estándar o una edición

(59) Cf. Carta apócrifa de Pedro a Santiago, II, 3: "Puesto que algunos de los que provienen de las naciones... han preferido la enseñanza ilegal y absurda del hombre enemigo" (La carta se conserva entre las Pseudoclementinas. B. Rehm - J. Irmscher, Die Pseudoklementinen I. Homilien, GCS 42 Berlin 1969). cf. Dunn, Unity and Diversity in the New Testament, p. 237-245; 288-296, en especial, n. 13, p. 410; A. Lindemann, Paulus im ältesten Christentum: das Bild des Apostels und die Rezeption der paulinischen Theologie in der frühchristlichen Literatur bis Marcion, Tübingen 1979. Cf. Ireneo, Adversus haereses, I, 26, 2: "Los llamados ebionitas... utilizan únicamente el evangelio según Mateo y rechazan al apóstol Pablo, acusándole de apostatar de la Ley”; Eusebio, H.E., III, 27, 4: "los ebionitas creían que era de todo punto necesario rechazar las Cartas del Apóstol, a quien llamaban apóstata de la ley, mientras que usaban exclusivamente el llamado Evangelio de los hebreos, sin importarles para nada los restantes".

(60) Cf. Tertuliano, Adv. Marcionem, III, 5, 4: "haereticorum apostolus".

(61) Cf. B.M. Metzger, The Canon of the New Testament, p. 251

(62) Es evidente que los criterios de canonicidad que exhiben los manuales, han sido elaborados $a$ posteriori, y que, ante un estudio apegado a los datos históricos, se revelan artificiales.

(63) Agustín, Contra Epistulam Manichaei, 5.

(64) Tertuliano, De Res., 63, 6: "Sed nihil mirum si odisti cuius auctorem quoque respuisti, quam et in Christo aut negare aut mutare consuevisti, proinde et ipsum Sermonem Dei qui 'caro factus est' vel stilo vel interpretatione corrumpens, arcana etiam apocryphorum superducens, blasphemiae fabulas". Cf. De praes., 17, 2; 38, 1-10. 
crítica de la Biblia. Ante esta situación, solo quedaba confiar en el texto que ofrecía la propia Iglesia. Los problemas en torno a la integridad del texto también muestran esta cierta 'autoridad' de la comunidad eclesial sobre el escrito sagrado.

3. En relación con la interpretación, Tertuliano conoce la dificultad del uso de la argumentación bíblica en polémica con los herejes y desaconseja discutir con ellos. Con su usual ironía, afirma: en la polémica, lo único que lograrás dar vuelta, no será la opinión del adversario, sino tu cerebro y tu estómago, y recuerda: lo que perderás será la voz y lo que ganarás con seguridad será la irritación (65).

Con mucho realismo, reconoce que en el debate los herejes, convencidos de poseer la verdad, dirán que nuestras Escrituras son las corrompidas y que nuestras interpretaciones son las falsas (66). Se llega así a un 'punto muerto' en la controversia. ¿Cómo acceder a la correcta interpretación de la Biblia, un texto tan amplio y tan variado, que contiene escritos de múltiples géneros? Frente a esta dificultad, en continuidad con Ireneo, insiste en que solo se puede dar con la correcta comprensión de la Escritura desde la verdadera doctrina cristiana, es decir, desde la regla de fe.

Solo se accede a la verdad de las Escrituras guiados por la regla de fe (67). Si bien la revelación nos es transmitida por la Escritura, para comprenderla rectamente nos es necesaria la regula fidei. La Tradición, entonces, es la que permite comprender la Palabra de Dios (68). Solo en comunión con la comunidad eclesial se reciben los textos sagrados, se reciben íntegros, y se interpretan correctamente:

La verdadera gnosis es la doctrina de los Apóstoles, la antigua estructura de la Iglesia en todo el mundo, y lo típico del Cuerpo de Cristo, formado por la sucesión de los obispos, a los cuales (los Apóstoles) encomendaron las Iglesias de cada lugar. Así nos llega sin ficción la custodia de las Escrituras, en su totalidad, sin que se le quite o se le añada alguna cosa, su lectura sin fraude, la exposición legítima y llena de afecto (por la Palabra) según las mismas Escrituras, sin peligro y sin blasfemia (69).

Aparecen claramente los mismos elementos destacados por Tertuliano: la canonicidad de los textos, su integridad y su correcta interpretación. Todo esto solo es posible en unión con la comunidad eclesial. Pero la relación entre Escritura y Tradición es afirmada también por los adversarios de Ireneo. En el Adversus haereses, denuncia:

Porque al usar las Escrituras para argumentar, la convierten en fiscal de las Escrituras mismas, acusándolas o de no decir las cosas rectamente o de no tener

(65) Cf. Tertuliano, De praes., 16, 2; 17, 4.

(66) Cf. Tertuliano, De praes., 18, 3.

(67) Adversus haereses, IV, 35, 4: “Por nuestra parte seguimos como Maestro al único Dios verdadero, mantenemos la regla de la verdad de sus palabras (regulam veritatis habentes ejus sermones), y todos afirmamos las mismas doctrinas. Pues sabemos que hay un solo Dios, Creador de todas las cosas...".

(68) Cf. J. Fantino, La Théologie d'Irénée. Lecture des Éscritures en réponse à l'exégèse gnostique. Une approche trinitaire. Paris 1994, pp. 26-34.

(69) Ireneo, Adversus haereses, IV, 33, 8. 
autoridad, y de narrar las cosas de diversos modos: no se puede en ellas descubrir la verdad si no se conoce la Tradición. Porque, según dicen, no se trasmitiría (la verdad) por ellas sino de viva voz, por lo cual Pablo habría dicho: 'Hablamos de la sabiduría entre los perfectos, sabiduría que no es de este mundo’ (70).

Así, una vez más, aparece clara la relevancia de la tradición 'eclesial' en el proceso de la interpretación del texto sagrado (71). Cada grupo interpreta a partir de las precomprensiones de la propia comunidad.

Tertuliano, por su parte, también destaca el protagonismo de la regula fidei. Basándose en Lc 18, 42 afirma: "Fides, inquit, tua te salvum fecit, non exercitatio Scripturarum” (72). Tu fe (es decir, la regla de fe), te ha salvado, y no la práctica de las Escrituras. Lo que da la seguridad, es la fe recibida de la Tradición apostólica, y no la pericia en los textos sagrados.

La investigación bíblica solo es legítima cuando se mantiene intacta la regla de fe (73); los herejes, por el contrario, interpretan solutis a regula veritatis, es decir, desvinculados de la regla de la verdad (74). "La Escritura permanece sometida al criterio de la doctrina de los Apóstoles, su natural propietaria, y esa doctrina se encuentra resumida en la regla de fe. Por tanto, la Escritura debe ser siempre interpretada según la regla de fe” (75).

Tal como se ha visto, junto a la regla de fe, Tertuliano propone otra precomprensión para interpretar la Biblia, se trata de las exigencias de la razón: El correcto contenido de la Escritura debe ser Deo dignus, es decir, digno de Dios. Es un concepto que tiene una larga historia en el pensamiento antiguo, tanto filosófico como teológico (76). Tertuliano lo desarrolla en varias de sus obras, pero especialmente en el Contra Marción. Este principio apela al sentido común, a las nociones comunes, al consenso de todos; pero ciertamente es problemático establecer qué es lo digno de Dios. En otro lugar, este mismo argumento aparece en labios de Celso, un pagano anticristiano (77), pero, ipara mostrar que la encarnación y la muerte en cruz son indignas de Dios, y por tanto hay que negarlas! Ante esto, nos podemos preguntar: ¿Quién establece lo que es digno de Dios? Nos encontramos nuevamente ante una precomprensión, que proviene no de la tradición eclesial esta vez, sino de la razón, pero que igualmente determina la interpretación de un texto bíblico.

(70) Ireneo, Adversus haereses, III, 2, 1, 1Co2, 6.

(71) Cf. Clemente, Strom., VII, 106, 4: “Así Basílides, a pesar que se atribuye como maestro a Glaucia, intérprete de Pedro, como ellos alardean; así también Valentín, se pretende que escuchó a Teudas, y este era familiar de Pablo (...) Simón había escuchado por poco tiempo la predicación de Pedro".

(72) Tertuliano, De praes., 14, 3, cf. Lc 18, 42.

(73) Cf. Tertuliano, De praes., 12, 5.

(74) Cf. Tertuliano, De pudicitia, 8, 12.

(75) S. Vicastillo, en Tertuliano, "Prescripciones" contra todas las herejías, p. 108. Sobre la regla de fe como guía en la interpretación bíblica, cf. Adv. Praxean, 20; De pudicitia, 8.

(76) Cf. M. Sheridan, Digne Deo: A Traditional Greek Principle of Interpretation in Latin Fathers, en L'Esegesi dei Padri latini, XXVIII Incontro di studiosi dell'antichità cristiana, vol. I. SEA 68, Roma 2000, pp. 23-33; R. Braun, Tertullien. Contre Marcion (SCh 365), Paris 1990, p. 46.

(77) El filósofo pagano, Celso, en su Discurso verídico, afirma: “Luego, no hay que examinar si está

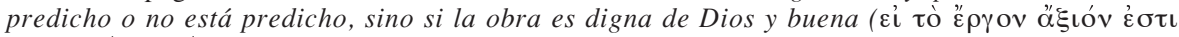

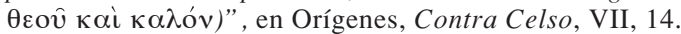


Finalmente, frente a la tarea de interpretar correctamente, Tertuliano recurre también a la Biblia para comprender la Biblia, invitando a aclarar un texto a la luz del resto de la Escritura: "Secundum plura intellegi pauciora" (78). Se trata de un principio común en la tradición clásica, que consiste en aclarar Homero con Homero (79). En esto, los cristianos son herederos de la gramática pagana. Entre los exegetas cristianos, son abundantes las referencias a reglas literarias de interpretación basadas en la naturaleza misma de los textos. Ellas han sido bien estudiadas, y aquí se mencionan solo para completar el cuadro general (80).

\section{REFLEXIONES CONCLUSIVAS}

La primera reflexión conclusiva coincide con el punto de partida del presente artículo, es decir, la constatación de la insuficiencia del texto solo. El escrito, aun el inspirado, solo se vuelve significativo en una tradición que le reconoce un status determinado y lo interpreta.

Esta constatación tiene su fundamento histórico en el hecho de que la Iglesia subsistió algunas décadas sin un Nuevo Testamento escrito. La plenitud de toda revelación es Cristo en persona. Por lo tanto, la fuente de toda verdad es el Evangelio que Cristo mismo "proprio ore primum promulgavit" (81), luego este Evangelio fue transmitido oralmente por los apóstoles (así, la predicación apostólica es anterior a los documentos escritos), y finalmente fue puesto por escrito por los apóstoles y los varones apostólicos (82). Pero estos escritos gozaron de autoridad en la medida que la Iglesia los reconoció como inspirados.

En el proceso de la formación del canon bíblico queda de manifiesto una compleja prioridad de la Iglesia sobre el texto sagrado. Solo se confía en el texto si ya se confía en la Iglesia, y la Iglesia confía solo en los textos que están de acuerdo con la regla de fe. Esta 'prioridad' es ejercida por la Iglesia en la selección de los libros inspirados, en su transmisión íntegra y en su interpretación.

Otra constatación que se ha podido hacer por medio de este recorrido es la relevancia o, más bien, el protagonismo de las convicciones previas del lector a la hora de interpretar un determinado texto. Dicho de modo negativo: toda lectura de la Escritura es prejuiciosa; no hay 'lectura neutra' del texto sacro. Dicho de modo positivo: todo contacto con la Escritura está guiado por una precomprensión, concedida por la comunidad, que permite que el texto se vuelva significativo (83).

El primer 'pre-juicio' aportado por la comunidad para la lectura de un texto es el de la canonicidad. Un desacuerdo en este punto repercute necesariamente en la

(78) Tertuliano, Adv. Praxean, 20. Cf. R.P.C. Hanson, Tradition in the Early Church, p. 108.

(79) Cf. R. Pfeiffer, Historia de la filología clásica. Desde los comienzos hasta el final de la época helenística, Madrid 1981, pp. 400-403.

(80) M. Simonetti, Lettera elo allegoria. Un contributo alla storia dell' esegesi patristica (SEA, 23), Roma 1985; R. Trevijano, La Biblia en el cristianismo antiguo, Navarra 2001, pp. 29-175.

(81) Concilio de Trento, Decretum de libris sacris, DH 1501; cf. Constitución dogmática Dei Verbum, 7.

(82) Cf. Constitución dogmática Dei Verbum, 7.

(83) En algunos casos, como hemos visto, el protagonismo de la precomprensión puede llegar al extremo de suprimir o modificar materialmente el texto sagrado. 
valoración e interpretación de un texto. Además de la canonicidad, hay también un 'pre-juicio' doctrinal que guía la lectura. Cada exegeta comprende el texto buscando la armonía con la tradición doctrinal que ha recibido o con los propios principios doctrinales que ha elaborado. La diferencia central entre un exegeta y otro no es tanto su habilidad o su técnica sino la tradición interpretativa a la que pertenece. Los cristianos se agrupan no de acuerdo a su habilidad exegética sino de acuerdo a sus 'pre-juicios doctrinales básicos', es decir, de acuerdo a la regla de fe. Por lo tanto, la ortodoxia no es el simple fruto de una buena exégesis del texto, ni la herejía es la consecuencia de falta de destreza exegética. Al momento de interpretar un texto, más que la habilidad exegética, importan las convicciones previas del lector, es decir, la regula fidei.

De este modo, la precomprensión católica de la Escritura es la regla de fe, lo que algunos han llamado 'el canon dentro del canon' (84). Hay que reconocer, así, que la Tradición viva de la Iglesia tiene un gran protagonismo en la interpretación bíblica.

Esto no quiere decir que la Escritura esté en un segundo grado respecto de la regla de fe. La Escritura, interpretada a la luz de la regla de fe, es la norma non normata. La regula fidei no agrega elementos que no se encuentran en la Escritura, sino que la cualifica (reconoce su canonicidad) y la interpreta correctamente. Tal como afirma O. Kuss: "Si bien la regla de fe es la última y más alta instancia para corregir el conocimiento de la revelación divina y, consecuentemente, del sentido legítimo de la Sagrada Escritura, la Escritura sigue siendo la fuente de la revelación” (85). Es decir, la 'autoridad' de la regla de fe y, por tanto, de la Iglesia, sobre las Escrituras, está en función del reconocimiento de la canonicidad y de su correcta interpretación.

El otro 'pre-juicio' que se constata es el de la razón. Ciertos presupuestos racionales también guían la lectura de la Escritura. En diversos ambientes cristianos, e incluso paganos, los exegetas perciben la necesidad de armonizar la explicación del texto bíblico con la razón. Es preciso comprender las Escrituras en modo digno de Dios. La razón también pone límites a la interpretación. Naturalmente, a este punto, surge la pregunta: ¿Quién establece lo que es digno o indigno de Dios? El pagano Celso y los docetas, por ejemplo, afirmaron que la encarnación es indigna de Dios. Cuando el mensaje bíblico parece ir contra la razón, la regla de fe tiene una palabra que decir.

$$
* * *
$$

A partir de lo dicho anteriormente, es posible ensayar una síntesis. El proceso de interpretación de la Escritura se realiza en el marco de una triple exigencia: Las exigencias de la fe, las exigencias de la razón y las exigencias del texto.

Desde sus propias convicciones doctrinales y racionales, cada exegeta comprende la Escritura a partir de las exigencias propias del texto, es decir, a partir de

(84) Cf. B.M. Metzger, The Canon of the New Testament, pp. 275-282.

(85) O. Kuss, Zur Hermeneutik Tertullians, en Neutestamentliche Aufsätze. Festschrift für Prof. J. Schmid zum 70. Geburstag, Regensburg 1970, p. 150. 
las reglas de interpretación literarias, propias de su escuela. El resultado de esta exégesis no puede entrar en conflicto ni con la razón ni con la regla de fe. Si esto ocurre, el lector busca una interpretación que supere este conflicto. Pero no se trata de un proceso lineal, puesto que en la misma investigación de los textos, el exegeta se ve impulsado, por una, a precisar el contenido de la fe, es decir, el alcance real de la regla de fe; y, por otra parte, a iluminar la razón con la revelación.

De este modo, queda claro el protagonismo y la necesidad de las precomprensiones -ya sea doctrinales como racionales- en el proceso de la interpretación bíblica. La tradición, que en contexto católico se expresa por medio de la regla de fe, adquiere una importancia mayor de la que se acostumbra a otorgarle, y se muestra históricamente la insuficiencia de la pretensión de la 'Sola Scriptura'.

\section{RESUMEN}

El artículo estudia la relación entre la regla de fe, la razón y la Escritura durante los tres primeros siglos de la era cristiana. Siglos en que se estableció el canon del NT y los criterios iniciales de hermenéutica bíblica. En la primera parte, se estudian casos extremos de interpretación bíblica, tomados de los más diversos ambientes, que manifiestan claramente la relevancia de la regla de fe y de la razón como precomprensión para la lectura de textos bíblicos. En la segunda parte, siguiendo a Tertuliano y a Ireneo, se estudia cómo comprendieron ellos la relación entre Tradición y Escritura.

La investigación muestra el protagonismo y la necesidad de las precomprensiones (doctrinales y racionales) en el proceso de la interpretación bíblica: Cada exegeta comprende la Escritura desde sus propias convicciones doctrinales y racionales, y a partir de las exigencias propias del texto. La tradición, que en contexto católico se expresa por medio de la regla de fe, adquiere una importancia mayor de la que se acostumbra a otorgarle, y se muestra históricamente la insuficiencia de la pretensión de la 'Sola Scriptura'.

\section{ABSTRACT}

The article looks into the relationship between regula fidei, reason and Scripture during the first three centuries of the Christian era. During these centuries the canon of the New Testament and the early biblical hermeneutic criteria were established. In the first part, the article presents extreme cases of biblical interpretation, taken from various settings, which clearly reveal the relevance of the rule of faith and reason as the foundation for understanding the biblical texts. Then the author, following Tertullian and Irineus, moves on to look at the way they understood the relation between Tradition and Scripture.

This investigation proves the necessity and prominent role of the pre-comprehension (doctrinal and rational) in the process of the biblical interpretation. Every exegete understands the Scripture from his own doctrinal and rational convictions and from the text's own demands. The tradition, which in the catholic context is expressed by means of the rule of faith, acquires greater importance than the one usually assigned, and shows the insufficiency of the of the 'Sola Scriptura' endevour. 